\title{
Water Supply Dilemma in Nigerian Rural Communities: Looking towards the Sky for an Answer
}

\author{
H. T. Ishaku ${ }^{1}$, M. Rafee Majid ${ }^{1}$, A. P. Ajayi ${ }^{2}$, A. Haruna ${ }^{2}$ \\ ${ }^{1}$ Department of Urban and Regional Planning, Faculty of Built Environment, \\ Universiti Teknologi Malaysia, Johor Bahru, Malaysia \\ ${ }^{2}$ Department of Urban and Regional Planning, Federal University of Technology, Yola, Nigeria \\ E-mail: htishaku123@gmail.com \\ Received May 24, 2011; revised June 25, 2011; accepted July 27, 2011
}

\begin{abstract}
Access to safe water supply has great influence on the health, economic productivity and quality of life of the people. But meeting this need is one of the major challenges facing the rural communities of Nigeria today. The purpose of this review paper is to determine whether water supply have contributed effectively to health, social, and cultural development of Nigerian rural communities. Over $70 \%$ of households in rural communities do not have access to improved water supply. They rely solely on self-water supply (free source) such as rivers, perennial streams, water ponds and unprotected wells which is susceptible to water borne diseases such as typhoid fever, cholera, dysentery, malaria parasites etc. These rural populations are engaged in farming activities with low income level living in small scattered settlements thus, making provision of piped water supply very difficult. Governments' interventions towards rural water supply have been through the provision of hand-operated boreholes and wells. These sources yield little or no water during the dry season and are prone to frequent breakdown; leading water crisis and shortages. This situation forces households especially the women and children to spend more time walking longer distances during the dry season to trot water for domestic purposes. Given the fact that the publicly operated water supply have not been able to cope with increasing demand, there is a need for a paradigm shift from the public monopoly of water supply to an innovative approach. Rainwater harvesting technology appears to be one of such alternative approaches.
\end{abstract}

Keywords: Nigeria Rural Communities, Water Scarcity, Dilemma, Rainwater Harvesting

\section{Introduction}

Access to water is measured by the number of people who have reasonable means of getting an adequate amount of water that is safe for drinking, washing and essential household activities expressed as a percentage of the total population. It reflects the health of a country's people and the country's capacity to collect, clean and distribute water to consumers. Safe water includes treated surface water, as well as untreated but uncontaminated water from source such as natural springs and sanitary wells and protected boreholes. On average, a person needs about 20 liters of safe water each day to meet his or her daily metabolic, hygiene and domestic needs. In urban areas the source may be public standpipe located not more than 200 meters away. In rural areas the definition implies that members of the household do not have to spend a disproportionate part of the day fetching water [1].

On the other hand, the lack of access to adequate safe water supply contributes to death and illness, especially in children. Thus, the improvement of access to water is a crucial element in the reduction of under age mortality, morbidity, particularly in poor rural areas. Access to water also means that considerable amount of time women and children spend in fetching water could be used more effectively on other tasks, a key component in poverty alleviation efforts. Most but not all, of these people live in low-income countries and those at greatest risk are children and the elderly. Millions more people worldwide suffer from other water related disease, such as bilharzias, cholera and hookworm. Improvement in water supply and sanitation services tend to lead to improvement in peoples health and quality of their lives. 
Water related diseases are the single largest cause of human sickness and death in the world and disproportionately affects the poor. Without water people can not leave healthy and productive lives. Improved adequate safe water supply will lead to reduction of human suffering, increased productive capacities that at the end will reduce health care cost. This can only be realized if water is set in the broader context of health objectives [2]. The [3] reported that about 3.5 billion people worldwide (54\%) had access to piped water supply house connections. Another 1.3 million (20\%) had access to "improved water source" through other means than house connections including standpipes. Finally, more than 1.2 billion people $(16 \%)$ did not have access to improve source, meaning that they have to revert to unprotected wells or springs canals, lakes or river to fetch water. It should be noted however, that access to an improved source of water does not necessarily imply that it is safe to drink from that source.

Preliminary investigations revealed that majority of the rural communities in Nigeria do not have improved water supply systems such as piped water networks or boreholes, where such facilities exists are either malfunctioning or completely broken down and this force household to rely on available sources for domestic purposes. Women and children especially spend their productive and considerable time seeking for water in far distances from their homes. They rely solely on self-water supply source. Households not having access to improve water supply are vulnerable to many health problems. These water supply sources include shallow wells, rivers, springs, ephemeral streams and rainwater.

\section{Evolution of Water Supply in Nigeria}

Public water supply in Nigeria started in the early $20^{\text {th }}$ century [4] in only a few towns and was managed at the lowest administrative level. Amongst the early beneficiaries were Lagos, Calabar, Kano, Ibadan, Abeokuta, Ijebu Ode and Enugu. The schemes were maintained with revenue from water sales with virtually no operational subvention from the government. With the creation of regional governments in the early $1950 \mathrm{~s}$, the financial and technical responsibilities for developing new water schemes were taken over by these regional governments who assigned supervisory manpower to oversee operations and maintenance. The regional governments were however slow in setting up independent bodies to develop, operate and manage the water supply. The first water corporation was formed in the western region in 1966 which took over all the assets and liabilities, including the existing staff. The staff of the Water Division of the Ministry of Works was also transferred to the new corporation.

The Federal Government got involved in the management of water resources in 1976 when the Federal Ministry of Water Resources and the 11 River Basin Development Authorities (RBDAs) were created. The purpose of the RBDAs was to provide bulk water, primarily for irrigation of dry season farming in some selected project sites mostly located in rural areas of the country. They were not involved in anyway in the domestic water supply. Today, all the 36 states and the Federal Capital Territory of Abuja have water corporations or public utility boards managing their public water supply. Their efforts are supplemented, in many cases, by local governments who supply water to small villages within their jurisdictions.

Following the adoption of the National Water Supply and Sanitation Policy in January 2000, the Nigerian Government considered the provision of water supply services to be the domain of the Federal, State and Local Governments. However, the public sector was not successful in meeting more than a small portion of the demand for water by residential and commercial users. Services were critically in short supply. For example, out of the 85 million people [5] living in urban and semiurban areas, less than half have reasonable access to reliable water supply. Many urban households, often the poorest, end up purchasing water from private vendors at a higher price than the public supply. A few rural communities were provided with hand-operated boreholes and wells which yield little or no water during the dry seasons due to incessant breakdown and fall in the water table. Water supply services, where they exist, are unreliable and of low quality; and are not sustainable because of difficulties in management, operation and pricing as well as due to failure to recover costs. Many water supply systems show extensive deterioration and poor utilization of existing capacities, due to under-maintenance and lack of funds for operation.

Additionally, the high cost of imported equipment especially in terms of a depreciating currency and inadequate cost recovery policies contributed to large financial deficits in many State Water Authorities (SWAs). This left most SWAs dependent upon state subventions to finance the operations and maintenance of their water systems, to service debt and to finance new investments. But the states' own financial constraints often limited the amount of recurrent capital subventions, requiring the SWAs to defer maintenance and limit new investment. Fiscally, both in small towns and rural areas, the focus must be on phasing out of subsidies for maintenance altogether and restricting such subsidies to partial capital costs to engender greater community ownership. From the foregoing it becomes clear that water supply has suffered a serious management setback despite government 
efforts at improving the water sector, leaving the poor rural dwellers not benefited much from this noble plan. It was realized that public water supply was not only urban biased but in many cases fail to meet the increasing demand. The idea of hand pump borehole came to bear in the preceding decades.

The [6] revealed that rural water coverage in Africa was 45 per cent compared to 40 per cent in 1990, still leaving 237 million people unserved. Meanwhile, urban water coverage in Africa was much higher at 83 per cent in 2000, with only 37 million urban dwellers unserved. It is clear that rural areas of Africa are lagging significantly behind urban areas in water supply. This fact, coupled with high poverty levels in many rural areas and depressed levels of service sustainability, indicates a critical need for focused attention to the provision of potable water to rural communities in Africa. There is the need therefore, to addresses domestic water supply in the rural context only and many of the issues explored may not be appropriate for urban or peri-urban areas. There are a number of reasons why the sustainability of water services in rural Africa is generally quite low. Some of these are related to environmental and technical issues, while many are related to social and management issues. Currently, many rural water supply projects and programs focus on the goal of increasing service coverage through the implementation of new water systems and facilities. It is essential that this is accompanied by adequate attention to the crucial aspect of sustainability if any gains are not to be short-lived.

Rural water supply provision in Nigeria and indeed in many developing countries is characterized by low cost, simple technologies which can be operated, maintained and financed by poor rural communities or households. The choice of technology for improved water supplies is dependent on environmental, socio-economic and political conditions, includes: Protected springs; Hand pump equipped boreholes and wells; Rainwater harvesting; Hand-dug wells; Gravity-fed systems; and Small-scale pumped systems. There is no single technology option which can be used in all situations and each technology has specific advantages and limitations. This is because of the relative ease of access to water that does not usually need treatment prior to drinking.

In the past two decades hand pumps have become the principal technology for supplying water to million of people in rural communities in Nigeria. According [7] despite this low level of sustainability, hand pumps are likely to remain a major method of delivery in rural water supplies, as they are still considered most appropriate and popular solution in many case. This is mainly because of the relative ease of access to water and does not require treatment prior to drinking. Wells and boreholes with hand pumps were therefore promoted as the most viable option for rural water supply in many developing countries. In the past two decades hand pumps have become the principal technology for supplying water to over one billion people in rural areas in at least $40 \mathrm{de}$ veloping countries [8].

Despite this popularity of the hand pump, there are evidences that it has failed to deliver satisfactory levels of sustainability. In 1994, Diwi Consultant and BIDR estimated that $40 \%-50 \%$ of hand pumps were not working, and according to [9] there are currently approximately 250,000 hand pumps in Africa, less than half of which are operational. On the whole rural water supply in Nigeria has had many problems and unable to meet the challenges and have not contributed effectively to health, economic, social, and cultural development of Nigerian rural communities as many rely on self water supply for both domestic and irrigation purposes.

\section{Materials and Methods}

A retrospective study involving the use of journals, books and other related literature was employed in this review of water supply dilemma in Nigeria rural communities looking up towards the sky for answer. Data collected include household access to water supply, notable cases of cholera and case studies on water supply situation in Nigeria. The data are as presented below.

\subsection{Household Access to Water Supply}

In a study of water supply in Wukari town through partnership approach, [10] noted that the water demand for the northeast Nigeria was $30 \mathrm{l} / \mathrm{p} / \mathrm{d}$. World Bank estimates that an average 20 - 50 liters of safe water is needed by an individual for daily metabolic and hygiene. This figure is slightly above the national water requirements for Nigeria which pegs it at 231/p/d for rural areas and 601/p/ $\mathrm{d}$ for urban areas. In the same vein, [11] estimates that $12 \%$ of the world's population consumes $80 \%$ of the available water, leaving 1.1 billion people $\left(1 / 6^{\text {th }}\right.$ of world population) without access to adequate water supplies. This is aggravated by the fact that 2.4 billion people lack access to adequate sanitation facilities. It is estimated that by 2025 water shortages could affect two out of three persons globally, with developing nations most vulnerable. As young people make up higher population of developing countries relative to developed countries, they are disproportionately at risk.

\subsection{Recent Cases of Cholera in Nigeria}

A report from [12] indicated that a cholera epidemic was 
emergent, with about 350 deaths reported, in the Northern region of the country. Since the outbreak was reported across the nation with recent emergence in the South West, it was appealed to all the governors of the 36 states on the need for increased funding to combat the epidemic, yet the scourge seems to be raging unabated. The cholera death toll has rose to 431 in 11 states, as Bauchi, Borno, Yobe, Adamawa, Kano, Jigawa, and Taraba. Others are Katsina, Rivers, Ogun, Cross River, and Osun, while no fewer than 4,665 cases had been recorded. Cholera remains a global threat and is one of the key indicators of social development. While the disease no longer poses a threat to countries with minimum standards of hygiene, it remains a challenge to countries where access to safe drinking water and adequate sanitation cannot be guaranteed. Unprecedented heavy rains and flooding across the country have further accentuated this scourge in states where safe drinking water and sanitary facilities are scarce. Seasonal factors such as the rainy season with flooding, as well as poor hygiene conditions and population movements in the area contribute certainly to this unusually higher incidence of cholera.

It should be noted however, that cholera can easily be eradicated if we can provide clean water and maintain a good hygiene, but in the absence of that which prevails across the country the abundant water resources can be captured in form of rainwater for use. Below is a brief summary of cholera episodes in Nigeria (Table 1).

These figures are rather frightening as the so called deadly disease can be eradicated only if the water is set in the broader context of health objectives. Water related diseases are the single largest causes of human sickness

Table 1. Cases of cholera in Nigeria 2009/2010.

\begin{tabular}{|c|c|c|c|c|c|}
\hline $\mathrm{S} / \mathrm{N}$ & Cases of Cholera & Death recorded & Location & Causes & Source \\
\hline 1. & $\begin{array}{l}\text { World body raises alarm as } \\
\text { cholera kills } 1500\end{array}$ & 1,500 persons & Nigeria & $\begin{array}{l}\text { Lack of clean water and } \\
\text { basic sanitation }\end{array}$ & $\begin{array}{l}\text { http:www.nigeria.gdf.com/NGD } \\
\text { F PDF 29/102010 }\end{array}$ \\
\hline 2 & United Nations Officials & 1,500 persons & Nigeria & $\begin{array}{l}\text { Lack of clean water and } \\
\text { basic sanitation }\end{array}$ & $\begin{array}{l}\text { http:www.ctv.ca/CTVNEWS/To } \\
\text { pStories/20101025/Nigeria- } \\
\text { cholera-1010 }\end{array}$ \\
\hline 3 & Poor Surveillance & $\begin{array}{l}781 \text { persons dead } \\
13,000 \text { infected }\end{array}$ & Nigeria & $\begin{array}{l}\text { Lack of clean water and } \\
\text { basic sanitation }\end{array}$ & Photos/IRIN 5/6/2011 \\
\hline 4 & Cholera kills 800 in 2 months & 800 persons & Nigeria & $\begin{array}{l}\text { Lack of clean potable } \\
\text { water allows bacterial } \\
\text { diseases to blossom in } \\
\text { W/Africa }\end{array}$ & $\begin{array}{l}\text { http://www.cbsnews.com/sto- } \\
\text { ries/2011/09/10.../main } 685342 \text { sh } \\
\text { tml-similar-cahced }\end{array}$ \\
\hline 5 & $\begin{array}{l}435 \text { died between January and } \\
\text { August } 2010\end{array}$ & 435 persons & Nigeria & $\begin{array}{l}\text { Poor sanitary conditions } \\
\text { especially in rural areas }\end{array}$ & $\begin{array}{l}\text { Leadership Newspaper } \\
\text { http://www.leadershipedi- } \\
\text { tors/com/ns/index.php? }\end{array}$ \\
\hline 6 & $\begin{array}{l}\text { Cholera outbreak in northern } \\
\text { Nigeria }\end{array}$ & 45 Persons & $\begin{array}{l}\text { Borno } \\
\text { Maiduguri }\end{array}$ & $\begin{array}{l}\text { Lack of access to potable } \\
\text { water }\end{array}$ & Nigerian Tribune 5/9/2010 \\
\hline 7 & Cholera epidemics & 100 persons & Lagos & Lack of clean water & $\begin{array}{l}\text { http://www.allvoices.com/.../661 } \\
\text { 6387-100-deaths }\end{array}$ \\
\hline 8 & $\begin{array}{l}\text { Borno cholera death toll rises } \\
\text { to } 212\end{array}$ & 212 persons & $\begin{array}{l}\text { Borno } \\
\text { Maiduguri }\end{array}$ & $\begin{array}{l}\text { Poisoned water in } \\
\text { contaminated food }\end{array}$ & This day Newspaper \\
\hline \multicolumn{6}{|c|}{ Federal Government of Nigeria updates on cholera cases 28/09/2010 } \\
\hline 9 & $\begin{array}{l}\text { Cholera } 1,250 \text { dead } 13,000 \\
\text { infected }\end{array}$ & 1,250 persons dead & Nigeria & $\begin{array}{l}\text { Lack of access to potable } \\
\text { water in rural areas }\end{array}$ & $\begin{array}{l}\text { This day Newspaper } \\
\text { http://www.thisdayonline.com/ }\end{array}$ \\
\hline 10 & $\begin{array}{l}\text { Cholera } 1,250 \text { dead } 13,000 \\
\text { infected }\end{array}$ & $\begin{array}{l}781 \text { dead out of } 3,310 \\
\text { reported cases }\end{array}$ & Katsina & $\begin{array}{l}\text { Lack of access to potable } \\
\text { water in rural areas }\end{array}$ & $\begin{array}{l}\text { This day Newspaper } \\
\text { http://www.thisdayonline.com/ }\end{array}$ \\
\hline 11 & $\begin{array}{l}\text { Cholera } 1,250 \text { dead } 13,000 \\
\text { infected }\end{array}$ & $\begin{array}{l}118 \text { dead out of } 1,469 \\
\text { reported cases }\end{array}$ & Adamawa & $\begin{array}{l}\text { Lack of access to potable } \\
\text { water in rural areas }\end{array}$ & $\begin{array}{l}\text { This day Newspaper } \\
\text { http://www.thisdayonline.com/ }\end{array}$ \\
\hline 12 & $\begin{array}{l}\text { Cholera } 1,250 \text { dead } 13,000 \\
\text { infected }\end{array}$ & $\begin{array}{l}162 \text { dead out of } 2,651 \\
\text { reported cases }\end{array}$ & Borno & $\begin{array}{l}\text { Lack of access to potable } \\
\text { water in rural areas }\end{array}$ & $\begin{array}{l}\text { This day Newspaper } \\
\text { http://www.thisdayonline.com/ }\end{array}$ \\
\hline 13 & $\begin{array}{l}\text { Cholera } 1,250 \text { dead } 13,000 \\
\text { infected }\end{array}$ & $\begin{array}{l}94 \text { dead out of } 2,293 \\
\text { reported cases }\end{array}$ & Bauchi & $\begin{array}{l}\text { Lack of access to potable } \\
\text { water in rural areas }\end{array}$ & $\begin{array}{l}\text { This day Newspaper } \\
\text { http://www.thisdayonli ne.com/ }\end{array}$ \\
\hline 14 & $\begin{array}{l}\text { Cholera } 1,250 \text { dead } 13,000 \\
\text { infected }\end{array}$ & $\begin{array}{l}80 \text { dead out of } 1,381 \\
\text { reported cases }\end{array}$ & Gombe & $\begin{array}{l}\text { Lack of access to potable } \\
\text { water in rural areas }\end{array}$ & $\begin{array}{l}\text { Thisday Newspaper } \\
\text { http://www.thisdayonline.com/ }\end{array}$ \\
\hline 15 & $\begin{array}{l}\text { Cholera } 1,250 \text { dead } 13,000 \\
\text { infected }\end{array}$ & $\begin{array}{l}13 \text { dead out of } 118 \\
\text { reported cases }\end{array}$ & Zamfara & $\begin{array}{l}\text { Lack of access to potable } \\
\text { water in rural areas }\end{array}$ & $\begin{array}{l}\text { This day Newspaper } \\
\text { http://www.thisdayonline.com/ }\end{array}$ \\
\hline
\end{tabular}

Source: Field survey 2010 
and death in the World and disproportionately affects the poor population living and finding means of livelihood in the rural areas.

\subsection{Location}

Nigeria is located between latitudes $4^{\circ} \mathrm{N}$ to $14^{\circ} \mathrm{N}$ and longitudes $3^{\circ} \mathrm{E}$ to $15^{\circ} \mathrm{E}$ (Figure 1). It is bounded in the north by Niger Republic, in the west by Benin Republic and in the east by Cameroon Republic. The Chad Republic is to the northeast while the Atlantic Ocean is to its south through the Gulf of Guinea. The country got its name from its most prominent river, the Niger. Its other prominent rivers include Benue, Ogun, Osun and Imo. All of these rivers flow directly to the Atlantic Ocean while rivers Kaduna, Hadejia and Gongola flow to Lake Chad on the northeast border (Figure 2).

According to the official report from [13] census published by the National Bureau for Statistics, the total population of Nigeria was put at 140,003,542. The projected population for Year 2010 is estimated to be 154,671,153, based on average growth rate of $3.2 \%$ annually.

\section{Past Studies on Water Supply in Nigeria}

There have been studies on water supply in Nigeria over he years. Few of these include study conducted by [14-17]. These studies examined water vending and willingness to pay for water in Onitsha, deficiencies of piped water availability, improvement measures used by rural people of Ebonyi and Enugu States, and the water supply deficiency and its general impact on rural devel-

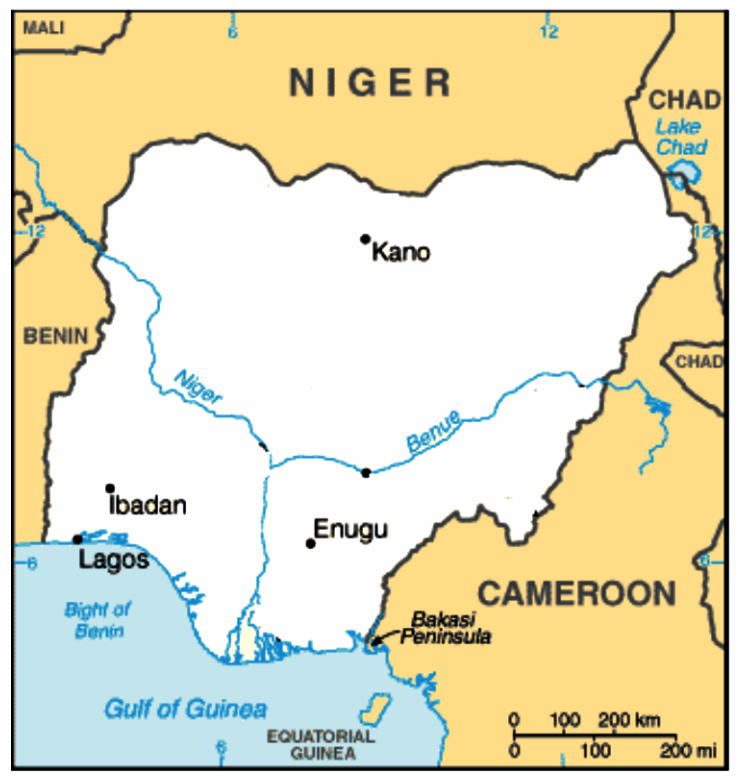

Figure 1. Map of Nigeria showing early beneficiaries of water supply.

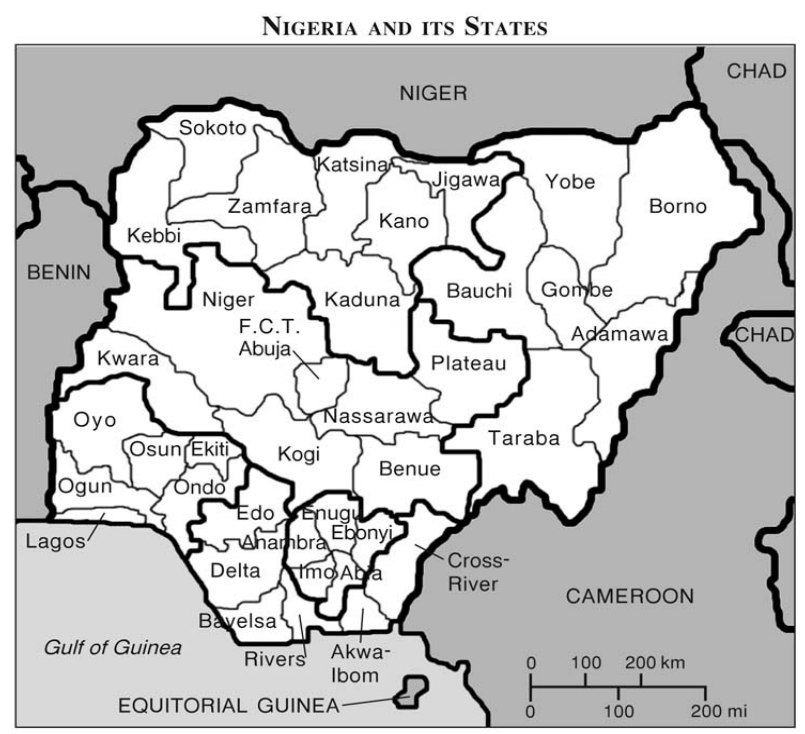

Figure 2. Map of Nigeria showing the 36 states and the Federal Capital Territory FCT Abuja.

opment within the Niger delta region Nigeria. The conclusions of these studies are that; water vending activities can yield valuable information for water supply planning and unexpected policy insight. Owing to deficiencies in piped water availability, households invest in coping strategies in the form of alternative supplies and storage facilities to supplement piped water. Most government aided improvement measures existing in the various communities studied are insufficient where provided and in most cases nonexistence. Finally, the water supply deficiency and its general impact on rural development within the Niger delta region and stated that there was a growing concern about the marginalization of the region in terms of infrastructure and social services provisions.

The vast majority of Onitsha obtains its water supply from an elaborate and well-organized water vending system which has been created and is operated by the private sector. Many of the households who purchase water from tanker trucks resell the water by bucket to individuals who cannot afford large storage tanks or who cannot be reached by the tanker trucks. However, during rainy season, the revenues from water vendor sales were still several times higher than water utility. On annual basis, households in Onitsha are already paying water vendors over twice the cost of piped water. Their study illustrates a rapid reconnaissance survey of water vending activities and willingness of households to pay for improved services. It is unfortunate that, as the study reveals, households still pay the water vendors as much as twice the cost of piped water during the rainy season when they can actually harvest water from rooftops or hand-dug wells which they have full control of owner- 
ship at their doorsteps. Consequently, the coping strategy adopted by resident in the form of other alternative has important implications for the consumers.

The weekly mean household water demand for the southwestern Nigeria was 1,108 liter per household (lph) as against the actual household water consumption of only $355 \mathrm{lph}$. As such, the people living in the area experienced acute water deficiency which had impacted negatively on their social, economic and political lives despite the fact that the region has abundant water resources, more than any part of Nigeria. It should be noted however, that the Niger Delta region of Nigeria has the highest annual rainfall and by extension enjoys abundant water resources. The findings of the study on water deficiency in Ebonyi and Enugu states by Onyenechere revealed that most government aided improvement measures existing in the various communities studied are insufficient where provided and in most cases nonexistence. He concluded that government interventions in rural and urban water supply had not met the increasing demand there, subjecting the rural residents to untold hardship. Onyenechere suggested massive rainwater harvesting, community participation and enlightenment campaign for improving water supply in the study area.

The above scenarios point to the facts that public water supply systems in Nigeria are characterized by insufficient supplies and chronic deficits. The private water supply meanwhile has remained financially solvent and fostered a rapid growth in capacity through informal sector but characterized by high cost because of the private sector's perceived profit motives. Their studies revealed that the rural areas have benefited relatively little from water supply intervention compared to their urban counterparts. The reason why the rural communities are often ignored is because of their perceived low income level as peasant farmers who can not afford the prices of such improved water facilities.

\section{Discussions}

A brief look at the Nigerian policy on rural water supply reveals the national objectives to include the followings:

1) To assist all rural communities to obtain basic water supply facilities, while ensuring the assistance is directed to communities that are prepared to maintain their facilities.

2) To increase the capacity of local, state and federal government to assist communities to obtain basic water supply facilities that the communities themselves can maintain with support from private sector.

3) To increase the capacity of private sector at the state and local levels to construct high quality hand-dug wells, boreholes and to repair water supply equipment.

4) To supplement the National Primary Health Care Program by promoting better health practices, focusing on clean water, good hygiene, diarrhoea control and proper excreta disposal.

Accordingly, the policy the components of the proposed National Rural Water Supply will be implemented at community, local, state and federal levels, with each having clearly defined responsibilities. Over time it is expected that state level support for the local government will decrease as local government personnel gain experience and their capacity to implement water supply programs independently grows stronger. To ensure that substantial funds are available to implement a nationwide rural water supply investment program, the Federal Government will take the lead in mobilizing domestic funds and external assistance for the implementation of the program. Financing operations and maintenance will be the responsibility of individual communities. The technology chosen should give the community the highest service that it is willing and able to pay for, will benefit from and has the institutional capacity to sustain.

As in most government policies regarding rural development, rural water supply has lagged behind its urban counterpart. This situation forces the households in the rural areas to adopt a coping strategy and rely on the free sources which are precursors to water related diseases [18-20] reported that about $80 \%$ of the health problems in developing countries can be linked to inadequate water and sanitation, claiming the lives of nearly 1.8 million children every year and leading to the loss of an estimated 443 million school days for the children who suffer from water related ailments. It was reported in the New Nigerian newspaper that another cholera outbreak had been recorded in northern Nigeria, claiming over 80 lives including the most recent one in Yobe state. In Adamawa state alone it claimed the lives of 27 persons and with over 120 families affected in Demsa Local Government Council in 2009.

It was reported by [21] that cholera has killed more than 1,500 people in Nigeria. This report further stated that the death toll is four times more than what was revealed in August of the 2009. The Ministry of Health had in August warned of a possible nationwide outbreak of the disease when about 350 deaths were reported in the Northern part of the country. The World Health Organisation (WHO), in its global report on the global outbreak of the disease around the world, claimed that 29,115 cases, including 1,191 deaths, have been reported between January 4 and October 3 2010, in 144 local government areas in 15 states, including the Federal Capital Territory. "The outbreak is still ongoing and spreading to new geographical areas. Severe flooding and displace- 
ment of large numbers of people have occurred, aggravating the situation," the report added.

Cholera remains a global threat and is one of the key indicators of social development. While the disease no longer poses a threat to countries with minimum standards of hygiene, it remains a challenge to countries where access to safe drinking water and adequate sanitation cannot be guaranteed. Unprecedented heavy rains and flooding across the country have further accentuated this scourge in states where safe drinking water and sanitary facilities are scarce. Seasonal factors such as the rainy season with flooding, as well as poor hygiene conditions and population movements in the area contribute certainly to this unusually higher incidence of cholera.

From the aforementioned it is clear that the public water supply has not been able to manage the water sector in Nigeria effectively. The result has not been successful in meeting more than a small portion of demand by residential and commercial users. Services are in critically short supply. Many households, often the poorest, end up purchasing water from private vendors at much higher prices than from public supply. Water service where they exists are unreliable and of low quality and not sustainable because of difficulties in management, operation, pricing and failure to recover cost. Many public water supply systems show extensive deterioration and poor utilization of existing capacities due to under maintenance and lack of funds for operation.

It was also reported by [22] that Gwoza and Biu local government councils of Borno State has recorded cholera outbreaks and the state government have approved the sum of N100 million $(\$ 625,000)$ for the control of the epidemic in the affected villages. This amount that could have been used to provide the rural people with clean, safe water supply and good environmental sanitation would have averted this outbreak of killer disease if only water supply was set in the broader context of health objectives. A situation [23] regarded as "putting the last first" in our rural development programs.

The underlying premise is that the public water supply in Nigeria rural communities where it is provided has not been able to cope with increasing demand. This is as a result of incessant breakdown of the water facilities, lack of personnel to undertake routine maintenance and the fall in the water table especially during the dry seasons. Above all, the communities view such intervention as external and tend to believe that it is the responsibility of the public authority to maintain the water facilities. In most cases these water projects were poorly conceived and haphazardly implemented without recourse to the inputs from community members. The result has been constant water crisis and shortages over the years

\section{Is Rainwater Harvesting the Answer?}

This question is highly debatable depending on the context in which it is used. However, rainwater harvesting is a technology used to collect, convey and store rainwater from relatively clean surfaces such as a roof, land surface or rock catchments for later use. The collected water is generally stored in a rainwater tank or directed into mechanisms that can recharge ground water. Rainwater harvesting can provide water for human consumption, reduce water bill and lessen the need to build reservoirs which may require the use of valuable land. Rainwater harvesting has been practiced for over 4.000 years throughout the world. It has provided drinking water, domestic water and water for livestock, water for small irrigation and a way to replenish ground water levels. Traditionally, rainwater harvesting has been practiced in arid and semi arid areas. It has become an integral part of societies in remote places where piped water and reliance on wells is not an option.

Surface and ground water supplies will not be able to meet future demand, water conservation and development of alternative water supplies have become necessary [24]. Rainwater harvesting was suggested as an alternative source of water supply. Rainwater harvesting captures diverts and stores rainwater for later use. Captured water is often used in landscaping, because it is free of salts and other harmful minerals and does not have to be treated. It is useful in attracting and providing water for wildlife. Implementing rainwater harvesting techniques will directly be beneficial to households, thereby reducing demand on the water supply, reducing surface runoff erosion and contamination of surface water.

Domestic roof water harvesting (DRWH) is often considered a traditional method of water collection and storage. The practice of domestic roof water harvesting can be traced back to many centuries especially in countries like India, Sri Lanka, Kenya, Egypt etc where DRWH is mentioned in ancient inscription as far back as $5^{\text {th }}$ century B.C. However, types and methods DRWH have changed over time and many different systems are now available all over the world. In Tamil Nadu, the ancient people stored rainwater in public placed separately for drinking purpose and another for bathing and other domestic purposes and called them as oranies. They also form percolation tanks or ponds for the purpose of recharging irrigation or domestic wells. They periodically clean the water ways so as to obtain clean water throughout the year. These are instances in history that people constructed crude rubble bunds across river courses either for diversion of water or for augmenting the ground water.

For centuries people have relied on rainwater harvesting for households, landscape, livestock and agricultural 
uses [25]. Before the advent of large centralized water supply systems, rainwater was collected from roof and stored on site tanks known as cisterns. With the development of large scale, reliable water treatment and distribution systems and more affordable well drilling equipment, rain harvesting was relegated to the background, even though it offered a source of pure, soft low sodium water. Rainwater harvesting can save money even if someone lives where annual rainfall averages only $30 \mathrm{~mm}$ [26]. Money can be saved by collecting and storing rainwater and using it when the need arises. Efficient water use is increasingly important at personal, national and international levels. With the increase in human population and limited supply of both ground and surface water, we must use water wisely. Rainwater harvesting is an innovative approach anyone can use.

Harvesting rainwater offers many advantages. It conserves municipal and well water; it is free; gravity fed system conserves energy; it is low in salts and good for plants; and can reduce flooding and erosion. Rainwater provides an excellent primary, supplementary or alternative sources of water. In terms of quality, it generally falls between ground water and surface water. Rainwater can be used at multiple scales from residential to commercial and at the neighborhood or community level. A renewed interest in rainwater harvesting has emerged because of escalating environmental and economic costs of providing water by centralized water system or by well drilling. The health benefit of rainwater, and potential cost saving associated with rain water collection has further spurred this interest. Since rain water is free, gravity fed, and good for domestic purposes, why do we bother ourselves with the public water supplies which is characterized by intermittent and insufficient services? We should embrace it wisely at personal, national, regional and international levels for the benefit of mankind and the health of the environment. Rainwater harvesting is an ancient technique enjoying a revival in popularity due to inherent quality of rainwater and interest in reducing consumption of treated water. Rainwater is valued for its purity and softness. It has nearly neutral $\mathrm{pH}$, and is free from disinfection by-products, salts and other natural and man made contaminants. Plants thrive under irrigation with stored rainwater. Appliances last longer when free from corrosive or scale effects of hard water. Users of portable systems prefer the superior taste and cleansing properties of rainwater.

\section{Conclusions}

The purpose of this review paper is to determine whether water supply have contributed effectively to health, social, and cultural development of Nigerian rural communities. Findings revealed that Over $70 \%$ of households in rural communities do not have access to improved water supply. They rely solely on self-water supply (free source) such as rivers, perennial streams, water ponds and unprotected wells which is susceptible to water borne diseases such as typhoid fever, cholera, dysentery, malaria parasites etc. Most of the rural dwellers especially women and children spend time trekking far distances of more than 3 kilometers to fetch water for domestic purpose. Households not having access to safe drinking water are vulnerable to many health problems.

This is a wake-up call for water supply planners, decision makers, donor agencies and external support agencies to take their share of the responsibility and support communities in their efforts to maintain the system that have been handed over to them. They cannot do it alone. Admittedly, the community members themselves should also play a crucial role in facilitating the active involvement of communities through self-help project in safe and secure water supply; but they are mostly financially incapacitated in raising the required funds for project execution. Community efforts and skills are indeed crucial, but their capacities and motivations need to be supplemented with capacities and mandates of government's agencies, NGOs and the private sector. Together they can create water supply service in which each stakeholder shoulders its share of the responsibility, in an institutional framework that addresses all functions needed to provide water to the people, including policy making, regulation, legislation, financing, support, operation and maintenance.

\section{References}

[1] World Bank Group, "Report: Access to Safe Water Supply," 2002.

http://www.worldbank.org/depweb/english/moules/enviro $\mathrm{nment} /$ water/htm accessed 7th March 2009

[2] C. Shaw, "Tri-Sector Partnerships: How They Work?" The Department for International Development Magazine, issue 18 Second Quarter, The Lime house Group, 2003. www.developments.org.uk/search? Searchable text $=$ improved accessed on $16^{\text {th }}$ October, 2004

[3] World Bank Group, "Report: Access to Safe Water Supply," 2004, accessed 7th March 2009. http://www.worldbank.org/depweb/english/modules/envir onment/water/htm

[4] Federal Republic of Nigeria, "Federal Ministry of Water Resources," Old Federal Secretariat Garki, Abuja, 2000. http://www.uneca.org/awich/Nigerian\%20Report. pdf

[5] Federal Republic of Nigeria, "The Nigeria Population Commission NPC Official Result for House and Population Census Figures," Bureau for National Statistics, Abuja, 1991.

http://www.nigerianstat.gov.ng accessed $10^{\text {th }}$ March, 2009

[6] UNICEF and WHO, "Progress on Drinking Water and 
Sanitation. A Millennium Development Goal MDG Assessment on progress for Children: A Report Card," 7th March, 2009. www.childinfo.org/water.html

[7] World Bank Group, "Report: Access to Safe Water Supply," 1997.

http://www.worldbank.org/depweb/english/modules/envir onment/water/htm accessed 7th June 2009

[8] H. Peter and B. Reed, "Rural Water Supply in Africa. Building Blocks for Hand pump Sustainability," Water Engineering and Development Center, Loughborough University, Leicestershire, LE11 3TU UK ed RWSN (2004 a \& b).

[9] H. Peter and B. Reed, Diwi Consultant and BIDR, "Rural Water Supply in Africa. Building Blocks for Hand Pump Sustainability," Water Engineering and Development Center, Loughborough University, Leicestershire, LE11 3TU UK ed RWSN (2004 a \& b).

[10] H. T. Ishaku, et al., "Planning for Sustainable Water Supply through Partnership Approach in Wukari Town Taraba State Nigeria," Journal of Water Resource and Management, Vol. 2, No. 10, 2010, pp. 916-922.

[11] WHO and UNICEF, "Joint Monitoring Progress on Drinking Water and Sanitation a MDG Assessment Report," 2000

http://www.worldbank.org/depweb/english/modules/ environment/water $/ \mathrm{htm}$

[12] Federal Ministry of Health (FMOH), "Federal Government Updates on Cholera. Cholera Kills 1,250 and 13,000 Persons Infected," Thisday Newspaper, 8/9/2010. http://www.thisdayonline.com/

[13] Federal Republic of Nigeria, "The Nigeria Population Commission Official Result for 2006 House and Population Census Figures," Bureau for National Statistics, Abuja, 2006.

http://www.nigerianstat.gov.ng accessed $10^{\text {th }}$ March, 2009

[14] D. Whittington, D. Laura and T. Xinming Mu, "Paying for Urban Services: A Study of Water Vending and Willingness to Pay for Water in Onitsha," World Bank, Nigeria, 1989.

[15] K. O. Adekalu, J. A. Osunbitan and O. E. Ojo, "Water Sources and Demand in South Western Nigeria: Implication for Water Development Planners and Scientists," ScienceDirect-Technovation, 2002.

http://www.sciencedirect.com/science?_ob=AritcleURL \&_udi=B6V8B-473M9TF-2\&_use $25^{\text {th }}$ April 2009

[16] E. C. Onyenechere, "Water Supply Measures Used by the Rural People of Ebonyi and Enugu States," Nigeria, IWA Publishing Alliance House, London, 2004. http://www.pcs.isiknowledge.com/uml/uml_view.cgi?_si $\mathrm{d}=1 \mathrm{Ck} 3511$ Ogno1M2mAo23 accessed on $21^{\text {st }}$ September 2009

[17] E. E. Nkwocha, "Water Supply Deficiency and Implications in the Niger Delta Region of Nigeria," 2008. http://www.springerlink.com/content/1bn488q22074k234 /fulltext.pdf

[18] WHO, "Progress on Drinking Water and Sanitation. A Millennium Development Goal MDG Assessment on progress for Children: A Report Card," 2000. www.childinfo.org/water.html accessed on 7th March, 2009.

[19] World Health Organization, "Global Water Supply and Sanitation Assessment Joint Monitoring Program for Water Supply and Sanitation Series Reports," New York, 2001.

[20] H. Ryan, "Private sector Development Blog: A market Approach to Development Thinking," International Finance Corporation World Bank, Water and Sanitation Category, June $25^{\text {th }} 2008$.

[21] United Nations, "Nigeria Has More than 1,500 Deaths in 2010. Lack of access to Clean Water and Sanitation," 2010.

http:/www.ctv.ca/CTV/TopStories/20601025/nigria-chol era-1010 25/10/2010

[22] M. Dauda, "Borno Government Approves N 100 million for Epidemic Control,” Leadership Newspaper, 2009.

http://www.leadershipnigeria.com and www-sul.standford.edu/Africa/Nigeria/nigerianews.html accessed on $7^{\text {th }}$ October, 2009

[23] C. Robert, "Rural Development: Putting the Last First," Prentice Hall, 1995.

www.infibeam.com/.../Robert-chambers/...Development.. $. / 0582644437 . \mathrm{html}-$

[24] P. E. Krishna and J. Hari, "The Success of Rainwater Harvesting in Texas," 3rd Edition, The Texas Manual on Rainwater Harvesting, Austin, 2005. www.twdb.state.tx.us/.../rainwater/.../rainwatercommittee Final report.pdf accessed $7^{\text {th }}$ March, 2009

[25] J. Kelvin and E. A. Ward, "Rain water Harvesting Texas Water Development Board," 2006. http://www.tx.us/homeindex.asp accessed on 27th March 2009

[26] A. P. Russell, D. Porter and V. Silvy, "Rainwater Harvesting Capturing Natures Best for Your Landscape," 2008.

$\mathrm{http} / / /$ texaswater.tamu.edu/conservation.rainwater.html accessed on 30th March 2009. 